\title{
Propriedades reológicas de blendas de polipropileno copolímero/polipropileno reciclado oriundo de recipientes industriais
}

\author{
Blends rheological properties of copolymer \\ polypropylene/recycled polypropylene from \\ industrial containers
}

Carlos Bruno Barreto Luna ${ }^{1}$, Wallisson Alves da Silva ${ }^{2}$, Edcleide Maria Araújo ${ }^{1}$, Danilo Diniz Siqueira ${ }^{1}$, Akidauana Dandara Brito de Oliveira ${ }^{1}$

\begin{abstract}
${ }^{1}$ Unidade Acadêmica de Engenharia de Materiais - UAEMa, Universidade Federal de Campina Grande - UFCG, Aprígio Veloso, 882, CEP: 58429-140, Campina Grande, Paraíba, PB, Brasil.

${ }^{2}$ Unidade Acadêmica de Engenharia Mecânica - UAEM, Universidade Federal de Campina Grande-UFCG, Aprígio Veloso, 882, CEP: 58429-140, Campina Grande, Paraíba, PB, Brasil.

e-mail: brunobarretodemaufcg@hotmail.com, wallissonalves11@hotmail.com.
\end{abstract}

\section{RESUMO}

Neste estudo, foram avaliadas blendas de polipropileno copolímero $\left(\mathrm{PP}_{\mathrm{Cop}}\right) /$ polipropileno reciclado $\left(\mathrm{PP}_{\mathrm{Rec}}\right)$, proveniente de baldes industriais pós-consumo, em três proporções diferentes (80:20; 60:40 e 40:60\% em peso). As blendas foram avaliadas por índice de fluidez, reometria de torque e reologia em regime dinâmico-oscilatório. Os resultados de índice de fluidez indicaram que a mistura de material reciclado com o $\mathrm{PP}_{\mathrm{Cop}}$ promove uma diminuição da massa molar, em comparação ao $\mathrm{PP}_{\mathrm{Cop}}$. Por reometria de torque, verificou-se que as blendas melhoraram a processabilidade em comparação ao $\mathrm{PP}_{\mathrm{Cop}}$. Além disso, as blendas apresentaram estabilidade ao longo do processamento, indicando ausência de degradação para as condições de processos utilizadas. Por meio dos ensaios em regime dinâmico-oscilatório, observou-se que, em baixas frequências $(<1 \mathrm{rad} / \mathrm{s})$, o $\mathrm{PP}_{\mathrm{Cop}}$ e as blendas $\left(\mathrm{PP}_{\mathrm{Cop}} / \mathrm{PP}_{\mathrm{Rec}}\right)$ apresentam um comportamento de fluido Newtoniano, enquanto que, para frequências maiores que $1 \mathrm{rad} / \mathrm{s}$, um comportamento de fluido pseudoplástico. Os valores dos pontos de intersecção $\left(G^{\prime}=G^{\prime}\right)$ das curvas de módulo de armazenamento (G’) e de módulo de perda (G”), em função da frequência angular $(\omega)$, indicaram que as blendas apresentaram uma redução da massa molar, sendo mais pronunciada na composição contendo $60 \%$ de $\mathrm{PP}_{\mathrm{Rec}}$. Os resultados reológicos das blendas $\mathrm{PP}_{\mathrm{Cop}} / \mathrm{PP}_{\mathrm{Rec}}$ foram de grande relevância, uma vez que permitem analisar o comportamento de blendas contendo material reciclado.

Palavras-chave: polipropileno, polipropileno reciclado, blendas poliméricas, reologia.

\section{ABSTRACT}

In this study, blends of copolymer polypropylene $\left(\mathrm{PP}_{\mathrm{Cop}}\right) /$ recycled polypropylene (PPRec) from industrial containers after consumption were evaluated in three different ratios (80:20, 60:40 and 40:60 wt.\%). The blends were evaluated by melt flow index, torque rheometry and rheology in a dynamic oscillatory regime. The results from the melt flow index indicated that the blending of recycled material with $\mathrm{PP}_{\mathrm{Cop}}$ causes a decrease in the molecular weight as compared to $\mathrm{PP}_{\mathrm{Cop}}$. By torque rheometry, it was verified that the blends showed improved processability in relation to $\mathrm{PP}_{\mathrm{Cop}}$. Also, the blends showed stability throughout the processing, indicating absence of degradation due to the process conditions used. By the dynamic-oscillatory regime tests, it was observed that, at low frequencies $(<1 \mathrm{rad} / \mathrm{s})$, the $\mathrm{PP}_{\mathrm{Cop}}$ and the blends $\left(\mathrm{PP}_{\mathrm{Cop}} / \mathrm{PP}_{\mathrm{Rec}}\right)$ demonstrated a Newtonian fluid behavior, whereas, at frequencies greater than $1 \mathrm{rad} / \mathrm{s}$, a pseudoplastic fluid behavior was observed. The values of the intersection points $\left(G^{\prime}=G^{\prime}\right.$ ') of the storage modulus curves ( $\left.G^{\prime}\right)$ and loss modulus $\left(G^{\prime}\right)$, as a function of the angular frequency $(\omega)$ indicated that the blends showed a reduction of the molecular weight, which was more pronounced in the composition containing $60 \% \mathrm{PP}_{\text {Rec }}$. The rheological results of the $\mathrm{PP}_{\mathrm{Cop}} / \mathrm{PP}_{\mathrm{Rec}}$ blends were of great relevance, since they allowed the analysis of the blends behavior containing recycled material.

Keywords: polypropylene, recycled polypropylene, polymer blends, rheology. 